\title{
Gender Norms and Agricultural Innovation: Insights from Six Villages in Bangladesh
}

\author{
Lemlem Aregu ${ }^{1}$, Afrina Choudhury ${ }^{2}$, Surendran Rajaratnam ${ }^{3}$, Catherine Locke ${ }^{4} \&$ Cynthia McDougall $^{3}$ \\ ${ }^{1}$ WorldFish, Yangon, Myanmar \\ ${ }^{2}$ WorldFish, Dhaka, Bangladesh \\ ${ }^{3}$ WorldFish, Penang, Malaysia \\ ${ }^{4}$ The School of International Development Studies, University of East Anglia, Norwich, UK \\ Correspondence: Lemlem Aregu, WorldFish Myanmar, C/O Dept. of Fisheries (Yangon Region), Bayint Naung \\ Road, West Gyogone, Insein Township Yangon, Myanmar. Tel: 95-01-647-521. E-mail: 1.behailu@cgiar.org; \\ lemlem627@yahoo.com
}

Received: February 22, 2018

doi:10.5539/jsd.v11n4p270

\author{
Accepted: May 11, $2018 \quad$ Online Published: July 29, 2018 \\ URL: https://doi.org/10.5539/jsd.v11n4p270
}

\begin{abstract}
The ability of development interventions to catalyse and support innovation for-and by - women and men is undermined by lack of specific understanding about how gender norms interact with gender relations and what this means for innovation. This is also the case for Bangladesh despite substantive research and development investments in the past decade that have placed emphasis on gender norms, particularly those inhibiting women and girl's education, women and girl's health, and women's economic empowerment. This paper analyses how men and women in South West Bangladesh perceive gender norms to affect their ability to innovate, adopt, and benefit from new technologies in aquaculture, fisheries and agricultural systems. Our qualitative findings from six villages in 2014 confirm that the engagement of women and men smallholders with agricultural innovation and its opportunities is gender-differentiated. We explore further: how gender norms shape these differences; which gender norms are most significant in the given context, when and for whom; and, finally, when and how are some women and men able to innovate in the context of these norms. In doing so, we highlight how gender norms interact with gender relations and wider structural inequalities to constrain and/or enable innovation for different women and men. We conclude that technical organizations seeking to promote innovation need to go beyond itemizing gender 'gaps' to engage more closely with underlying gender norms and the way they influence various women's, and men's, motivations, spheres of innovation, and valuations of outcomes.
\end{abstract}

Keywords: aquatic and agricultural innovation, Bangladesh, gender norms, gender relations, inequality, mobility

\section{Introduction}

\subsection{Background}

Promoting agricultural innovation among smallholders in developing countries remains essential to reducing poverty and an important avenue for improving food security, and enhancing productivity and income (Spielman, Ekboir, \& Davis, 2009). Innovation can be facilitated or inhibited by social, economic, institutional factors (Moore \& Westley, 2011) and there is long-standing recognition that gender norms are a key factor inhibiting women's capacity to innovate (Ogunlela \& Mukhtar, 2009). Accordingly, aquatic and agricultural innovations are increasingly expected to deliver income, nutrition, food security, and empowerment outcomes as well as agricultural growth (CRP AAS, 2012). While there is evidence that social inequalities and gender do matter for agricultural aquatic innovations, there is less understanding around how gender inequalities actually operate in these spheres (Meinzen-Dick et al., 2011; Sproule et al., 2015). This is true generally but also holds for Bangladesh where women's disempowerment is widely understood to be severe (Sraboni, Malapit, Quisumbing, \& Ahmed, 2014) due to their restricted control over resources and other restricting gender norms that are seen to disfavor women.

It is acknowledged in policy and intervention circles that gender norms are likely to affect the capacity of women and men to adapt and innovate new practices in aquatic agriculture differently (Lentisco \& Lee, 2014; Jahan \& Farnworth, 2014). However, gender norms have tended to be treated either as a 'given' that is beyond the scope 
of technologically-orientated interventions to address, but which are considered in targeting of activities, or they have become the focus of the universalized promotion of women's empowerment (Razavi \& Miller, 1995; Cornwall, 2016). Neither strategy has generally translated into significant gains for women's capacity to innovate or substantial gains for them in terms of gender equality and women's empowerment (Gill et al., 2010; Carr \& Thompson, 2014; Malhotra, Schulte, Patel, \& Petesch, 2009; Meinzen-Dick et al., 2011). Developing more effective approaches requires a new kind of evidence-base and we argue here that this needs to include improving our understanding of how gender norms influence innovation. Thus this paper asks which gender norms matter, for whom, and how they shape the ability of different women and men to innovate, adopt, and benefit from new technologies. We examine how far different women are able to renegotiate some gender norms around innovation and ask what this means for wider gender relations.

Our evidence comes from six villages in South West Bangladesh where WorldFish undertook research on small-scale aquatic and agricultural innovations in its CGIAR Research Program (CRP) on Aquatic Agricultural System (AAS) and Livestock and Fish (L\&F) (hereafter, the 'program'). We begin by raising questions about the ways in which gender norms are often handled in research and identify the theoretical starting points for our study. We then introduce the context and outline our methods. Our findings are presented in analytically-themed sections that relate to our theoretical starting points, and lead on to our final conclusions.

\subsection{Researching Gender Norms}

There is widespread consensus that gender relations and gendered decision-making are, in all contexts, underpinned by gender norms. Although gender norms, by definition, exist at the societal level, there are important variations in their force, interpretation and salience. Not only may they vary significantly from one community to the next, they are also contingent upon social identity and thus apply differently, for instance, to wealthy young unmarried women as they do to poorer married women with young children. Whilst gender norms often claim legitimacy in being traditional, they and their interpretation are historically specific (Agarwal, 1997). In fact, they are mutually and iteratively shaped by ongoing gendered social relations. In other words, gender norms - like all norms - are embedded in existing structural and institutional conditions and women and men use their agency to assert, resist and renegotiate gender norms to varying degrees in their everyday lives (Agarwal, 1997; Bennet, 2005; Elmhirst \& Resurrecion, 2008). In practice, women and men can and often do behave in ways that stretch and reshape prevailing cultural norms about gender (Agarwal, 1997; Kabeer, 1999).

However, current trends in agricultural research appear to implicitly frame gender norms as a set of relatively static cultural rules, largely about women's behavior (Kawarazuka et al., 2017; Okali, 2012). For example, the popularity for participatory group methodologies has provided public research forums in which communities, or at least those with authority, can articulate 'idealized' gender norms. These findings may tend to see norms as generalized, problematic for women, and as both unquestioned by, and unquestionable for, participants (Johnson, Lilja, Ashby, \& Garcia, 2004; Mosse, 1994). Agricultural research has done little to explore instances of changing gender norms (see Quisumbing et al., 2015) or to explore how far, in what way, and when do gender norms feed into individual decisions. Whilst relatively strong attention is increasingly being paid to gender norms around agricultural production in the field of agricultural research, other gender norms have not been addressed in this field, presumably being interpreted as unrelated or beyond their remit. Specifically, gender norms about family roles and responsibilities, as well as about expected behaviors in wider society, matter for how households, and individuals within households, make decisions about agriculture (Sumner, Christie, \& Boulakia, 2017). The, as yet, relatively static and narrow understanding in agricultural research of how gender norms influence gendered perceptions and gendered decision-making may fed into agriculture and development policy and programming approaches which either adapt to existing gender norms, are overly narrow, and/or promote an alternative set of universalized norms around women's empowerment.

In other words, whilst we know more in agricultural research about culturally-specific gender norms, and whilst there is now a wide recognition that they matter, we need to know more about how they matter, for whom, when and why. Accordingly, our approach sees gender norms as contextually-specific and attends to variations in the gendered social norms that matter for women and men people from different religions, wealth groups, at different points in their life course. We distinguish carefully between expressed norms and actual practices and deliberately extent our exploration of gender norms beyond those about agricultural production. Finally, we attend closely to women and men's narratives and experiences about innovative agricultural practices and the role that (un)changing gender norms has played in these. In doing so, we seek to contribute to a growing critical literature around how gender norms operate in agriculture (notably including: Sumner et al., 2017; Quisumbing et al., 2015). 


\subsection{Gender Norms in the Context of Bangladesh}

Bangladesh is the most climatically vulnerable country in the world to disasters such as flood, cyclone, coastal erosion and drought (Nokrek \& Alam, 2011) and within Bangladesh, the South West Coastal belt is particularly vulnerable. The extreme vulnerability of this region has been further exacerbated by ecologically inappropriate farming methods, especially shrimp farming. The resulting increase in salinisation of water and soil have made it hard to pursue alternative agricultural aquatic livelihoods. Decreasing resilience is evident in high rates of poverty, social marginalization, and growing rates of male outmigration. Although Bangladesh's economy has been growing over the past two decades, which has resulted in an overall decline of poverty, it remains a country of deep and extensive poverty and the poorest households have been marginalised from the increase in economic growth (UNICEF, 2009). The Human Development Index (HDI) for Bangladesh was 0.579 in 2016, but falls to 0.412 when adjusted for inequality, representing a 'loss due to inequality' of 39\% (UNDP, 2016).

Bangladesh's gender norms are rooted in its patrilineal inheritance system, and are closely linked to religious values, as well as practices such as veiling and purdah (Note 1). Women's mobility and visibility is severely restricted outside the home and women are seen as being the property of their father before marriage and their husband's after it. The country's Gender Development Index (GDI) of 0.520 in 2015 reflects the comparatively good representation of women in parliament (where they hold $20 \%$ of the seats) and the very marked absence of women from employment (where their participation rate is only $43 \%$ ). Despite formal equality before the constitution, personal religious laws governing keys aspects of family life (such as marriage divorce, inheritance, custody of children) are deeply inequitable for women. Though economic growth has provided many opportunities for women in Bangladesh it also holds an embedded challenge for them and presented a new set of challenges for gender inequality (Holmes, Mannan, Dhali \& Parveen, 2010). Gender-based violence, including rape, acid attacks, and domestic violence, is pervasive and appears to be rising (Khan, 2005). Development interventions have targeted women and girls, with emphasis on education, health and economic empowerment with many notable gains (World Bank, 2015). Despite this purdah remains a significant brake on women entering paid work (Asadullah \& Wahhaj, 2016). Development interventions have done little to address gender norms on women's mobility and more commonly interventions accommodate or work around these restrictions (IGWG, 2004). Critical commentators have noted, particularly in relation to microfinance, the ways in which men may retain power over women-focused initiatives and have raised concerns about increasing gender violence and women's burden of work (see Goetz \& Sen Gupta, 1996; Mahmud, 2003).

The study was conducted in the Satkhira, Barguna and Khulna districts of South West Bangladesh. The land here is made up of polders constructed during the 1960s as part of the Coastal Embankment Project (CEP), is densely populated, and extremely vulnerable to cyclones and rising sea water levels (Solidarities International \& Uttaran, 2012). Typically, people here rely on agricultural and aquatic resources for their livelihoods, with farming, fishing, aquaculture and livestock keeping all being important. Agricultural production and drinking water supplies on the polders has been threatened by natural and man-made problems particularly water-logging and salinization due to riverbed siltation, rising sea-level and the dramatic expansion of shrimp farming. The impact on livelihoods is exacerbated by the fact that land sizes are generally reducing through inheritance division and some lands are increasingly useless due to salinization. However, the degree of salinization, mostly of water but also of land, and its seasonal variation, as well as vulnerability to cyclones, tidal floods vary across villages. Shrimp farming was heavily promoted by the government in the 1990s but has only proved profitable for wealthier farmers. As well as salinization, shrimp cultivation has led to dramatic declines in resilience for whole communities due to conflicts over land ownership, including conversion of communal grazing lands (khaslands) to shrimp production, and the spoiling of agricultural lands for rice cultivation, as well as health problems arising from the lack of sweet water for drinking and washing purposes. Despite these difficulties, just three districts in the South West, including Khulna and Satkhira district studied here, still accounted for $80 \%$ of Bangladesh's shrimp production in 2012 (Solidarities International \& Uttaran, 2012).

Although infrastructure, particularly roads, and access to education, and to a lesser extent health, have been improving, many villages are poorly served and frequently rendered remote by rising waters. In many villages, particularly those less accessible to administrative centres, non-governmental organisations (NGOs) have been strong service providers substituting for the state's absence. Others, however, have found themselves marginalized. Social marginalization in this coastal belt is complex with extensive poverty interacting with a relatively high incidence of disability, ethno-religious groupings, political patronage and the relatively high vulnerability to climatic disasters. Employment opportunities have improved to some extent over the past decade, partly due to better infrastructure, opportunities with government and NGOs and for migration, and growing diversification into farm and non-farm activities. On-farm diversification has been particularly strong around 
vegetable farming and poultry keeping. Poverty is more extensive in Khulna and Satkhira districts, where according to the World Bank, nearly $50 \%$ and $60 \%$ of the population respectively fall within the so-called bottom $40 \%$, as compared to Barguna, where nearly $20 \%$ of the population fall into the bottom $40 \%$ (World Bank, 2016) Many in this region are, however, living in a situation of intermittent crisis as they face with recurrent shocks and declining opportunities for agricultural production.

WorldFish began promoting small-scale aquatic and agricultural innovations in 2013 in 16 communities across four districts in the South West in its Aquatic Agricultural Systems (AAS) Research Program. These field sites reflected the climate vulnerability, the livelihood reliance on aquatic agriculture systems, and the poverty of the southern polder zone. The villages were also chosen for their varying exposure to salinity, varying proximity to development infrastructure, and by the presence of partner organizations, the absence of intra and inter-community conflicts and women's willingness to participate in action research. The overall aim of AAS/L\&F was to improve the food security situation and overall wellbeing of impoverished people who depend on freshwater and costal ecosystems for their livelihood. AAS/L\&F was also focused on enhancing inclusiveness and equity within the existing social, economic and political structures that influence such environment-dependent livelihood sources. The program took a Participatory Action Research (PAR) approach engaging women and men farmers as farmer researchers working with teams of professionals in farmer field schools around problem areas identified by the community. These included increasing homestead vegetable production through improving seed selection, seed preservation and market access, as well as dealing with shading of ponds and developing fodder production. In addition to working with men and women in mixed gender groups, WorldFish has specifically targeted women in women-only groups and trainings.

\section{Methodology}

This study focuses on 6 of the villages selected from the 16 communities where WorldFish has been working (see figure 1). The data was collected between August and September 2014 using a qualitative methodology developed by the CGIAR's GENNOVATE initiative (see Badstue, Kantor, Prain, Ashby, \& Petesch, 2014). GENNOVATE is global study of 11 CGIAR Research Programs which focuses on how gender norms and agency shape women's and men's innovation in agriculture and natural resource management.

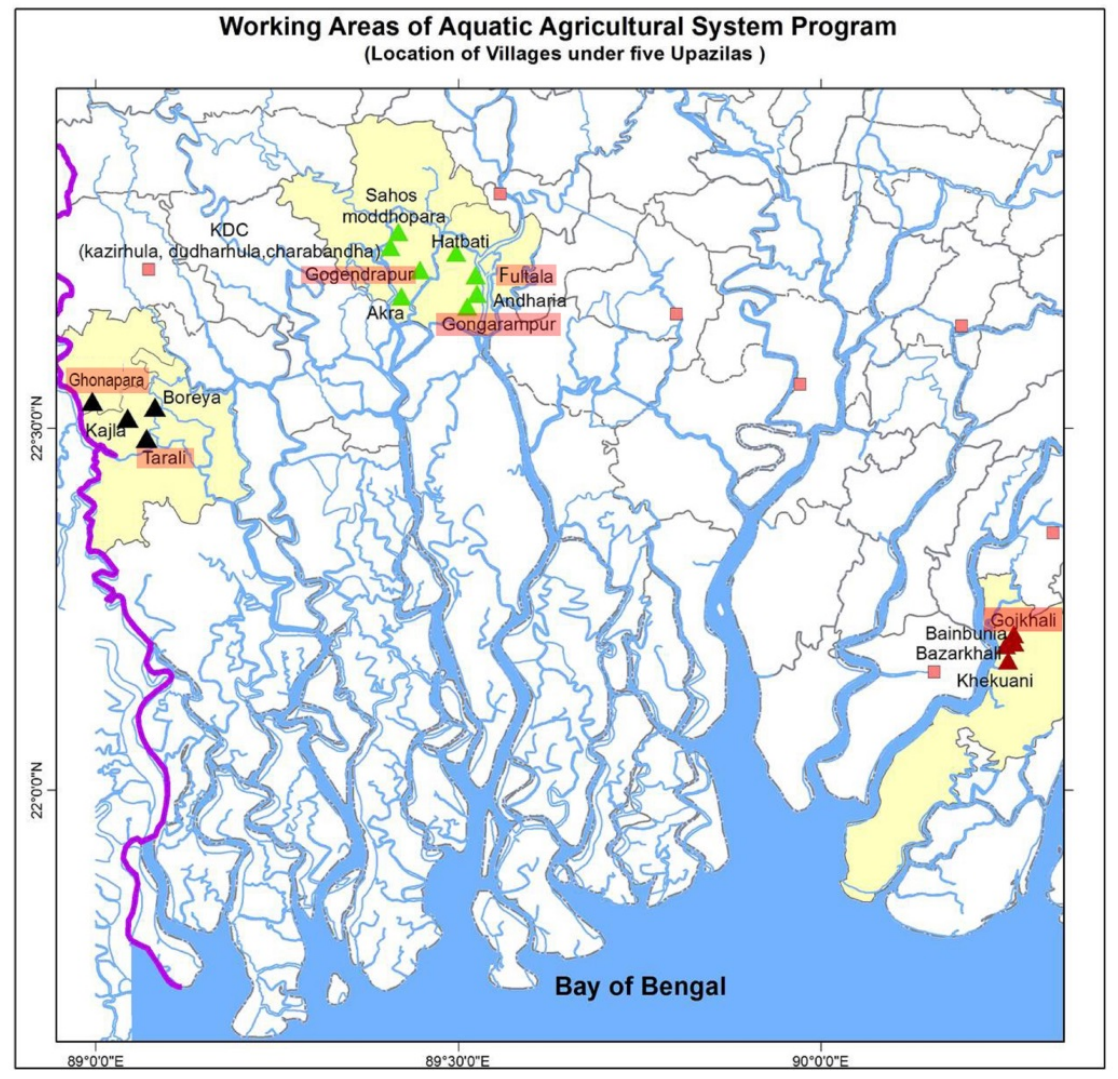

Figure 1. Map of the study sites in Bangladesh: 6 study sites highlighted in red: Satkhira (Polder 3)-high saline area; Khulna (Polder 29 and 30)-Medium saline area; and Barguna (Polder 42/F)- Low saline 


\subsection{Study Site Selection}

A sample of 6 villages was selected in order to make data collection and analysis manageable whilst also exploring the diversity of circumstances existing in the southern polder zone that were thought to be most relevant for this study. Accordingly, villages were selected by senior staff that were understood to be more or less economically dynamic and to experience greater or lesser gender inequalities whilst also maintaining representation of different agro-ecological zones and varying religious composition of villages. Table 1 below summarises the characteristics of the sample villages.

Table 1 . Summary characteristics of study villages

\begin{tabular}{|c|c|c|c|c|}
\hline Village & Salinity & Religious composition & Size & $\begin{array}{l}\text { Senior staff's estimation of economic dynamism and } \\
\text { gender inequality }\end{array}$ \\
\hline 1 & High & Predominantly Muslim & Relatively large & $\begin{array}{ll}\text { - } & \text { Relatively dynamic economically } \\
\text { - } & \text { Relatively lower gender inequality }\end{array}$ \\
\hline 2 & High & $\begin{array}{l}\text { Majority Muslim, } \\
\text { significant Hindu minority }\end{array}$ & Relatively large & $\begin{array}{ll}\text { - } & \text { Relatively dynamic economically } \\
\text { - } & \text { Relatively greater gender inequality }\end{array}$ \\
\hline 3 & Medium & Exclusively Muslim & Medium & $\begin{array}{ll}\text { - } & \text { Relatively less dynamic economically } \\
\text { - } & \text { Relatively greater gender inequality }\end{array}$ \\
\hline 4 & Medium & Predominantly Hindu & Medium & $\begin{array}{ll}\text { - } & \text { Relatively less dynamic economically } \\
\text { - } & \text { Relatively lower gender inequality }\end{array}$ \\
\hline 5 & Medium & Predominantly Hindu & Relatively small & $\begin{array}{ll}\text { - } & \text { Relatively dynamic economically } \\
\text { - } & \text { Relatively lower gender inequality }\end{array}$ \\
\hline 6 & Low & Predominantly Muslim & Relatively large & $\begin{array}{ll}\text { - } & \text { Relatively less economically dynamic } \\
\text { - } & \text { Relatively more gender inequality }\end{array}$ \\
\hline
\end{tabular}

Where salinity is high there is an extremely urgent need for diversification away from shrimp-farming and innovation with agricultural and aquatic alternatives that can tolerate salinization to guarantee survival and where salinity is low, villagers may have a more resilient foundation from which to experiment with new activities and ways of doing things, whilst maintaining existing livelihood activities. Predominantly Muslims villages in our sample were either in the highest salinity zones or in relatively poor villages with little infrastructure and high climatic vulnerability. The predominantly Hindu villages were medium salinity but with variations in infrastructure and access to government services and considerably or high exposure to climatic vulnerability.

\subsection{Data Collection and Analysis}

Sex-disaggregated data was collected through semi-structured interviews (SSIs) with individuals and small groups and focus group discussions (FGDs). The SSIs in each village explored: the profile of the community with key informants; the trajectories of women and men deemed by key informants to be 'innovators'; and the life histories of women and men who were poor or who had experienced poverty.

Table 2 shows the distribution of the SSI participants by tool, gender and religion. Whilst male participants included unmarried men, almost all women were married with only one unmarried woman and one widow being interviewed. Almost all these participants were members of WorldFish groups, as well as of other local development organization initiatives. The SSIs were recorded. 
Table 2. SSIs with individual women and men by type

\begin{tabular}{|c|c|c|c|c|c|c|c|c|c|c|c|c|}
\hline Tools/Villages & \multicolumn{2}{|r|}{1} & \multicolumn{2}{|c|}{2} & \multicolumn{2}{|r|}{3} & \multicolumn{2}{|r|}{4} & \multicolumn{2}{|r|}{5} & \multicolumn{2}{|c|}{6} \\
\hline Women: Men & Hindu & Muslim & Hindu & Muslim & Hindu & Muslim & Hindu & Muslim & Hindu & Muslim & Hindu & Muslim \\
\hline Community & \multicolumn{2}{|c|}{$1: 2$} & \multicolumn{2}{|c|}{ No information } & \multicolumn{2}{|c|}{$2: 2$} & \multicolumn{2}{|c|}{$1: 2$} & \multicolumn{2}{|c|}{$2: 2$} & $1: 2$ & \\
\hline \multicolumn{13}{|l|}{ Profile SSIs } \\
\hline Innovators & $1: 0$ & $1: 2$ & $0: 1$ & $2: 1$ & $0: 0$ & $2: 2$ & $2: 1$ & $0: 1$ & $1: 2$ & $1: 0$ & $0: 0$ & $2: 2$ \\
\hline \multicolumn{13}{|l|}{ Pathway SSIs } \\
\hline Life Histories & $1: 0$ & $1: 2$ & $2: 1$ & $0: 1$ & $0: 0$ & $2: 2$ & $2: 1$ & $0: 1$ & $1: 2$ & $1: 0$ & $0: 0$ & $2: 2$ \\
\hline SSIs & & & & & & & & & & & & \\
\hline
\end{tabular}

The FGDs were conducted with men-only and women-only groups on four different themes: pathways in and out of poverty (called the 'Ladder of Life'), gender norms, capacities for innovation and youth aspirations. The numbers in individual focus groups ranged from $7-10$. Although most participants were between 20 and 59 years of age, a few participants were over 70 years (Figure 2). The youth aspirations FGDs included those between 15 and 25 years of age. The ladder of life FGDs and the youth aspirations FGDs were held with those deemed to be 'poor' by key informants, whilst the others were also held with those deemed to be 'middle wealth rank' (as summarized in table 3). The FGDs were not recorded, instead they were annotated in Bangla. These notes tend to be bullet points supplemented with verbatim quotes where note-takers felt something important was said, but in even in these instances the identities of individual contributors were not recorded.

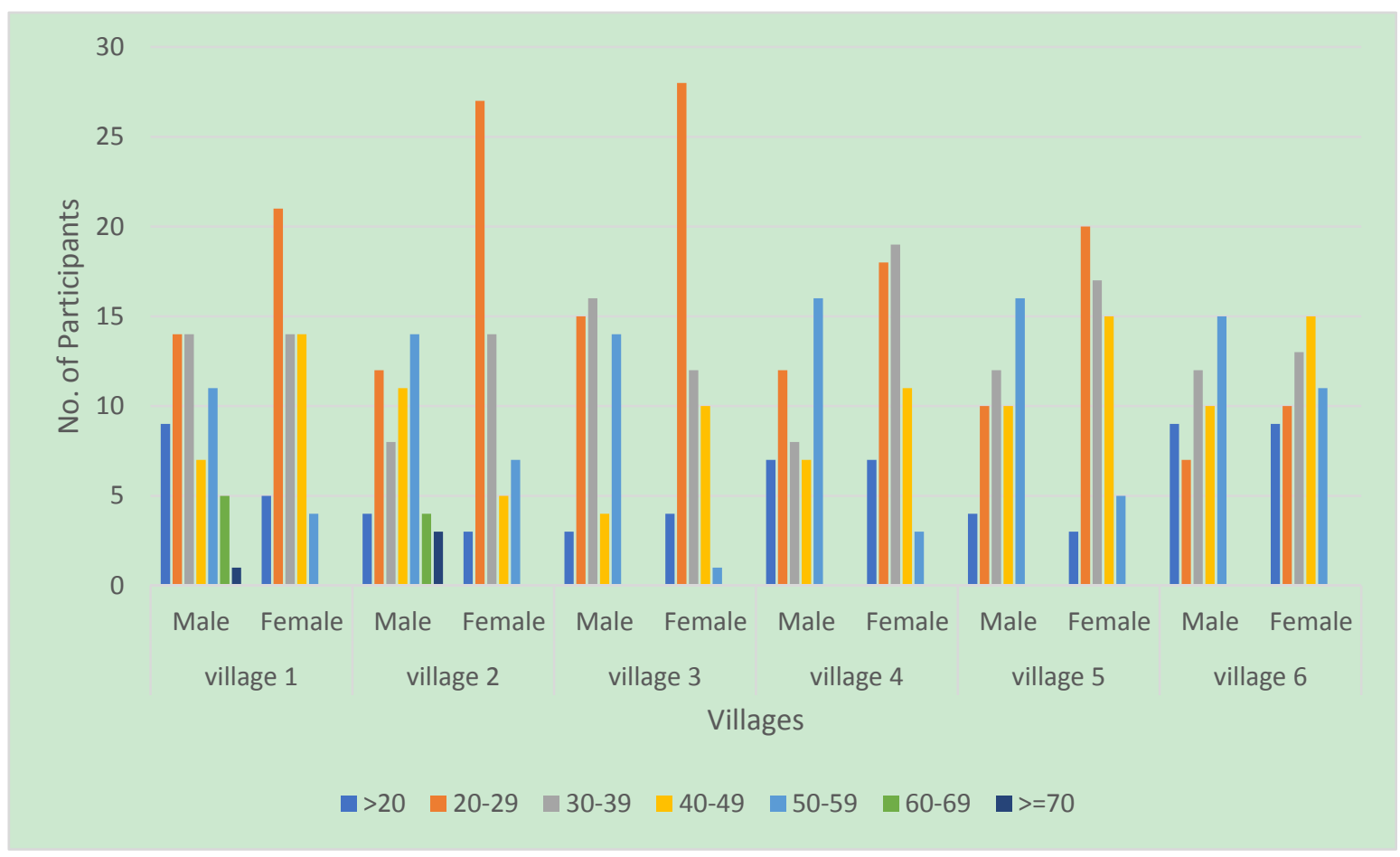

Figure 2. Numbers of participants in FGDs by sex and by age groups 
Table 3. Numbers of FGDs by theme, gender and 'wealth rank' (WR) in each village

\begin{tabular}{lll}
\hline FGD Tool & Men-only FGDs & Women's Only FGDs \\
\hline Ladder of Life & 1 with poor & 1 with poor \\
Gender Norms & 1 with poor and 1 with middle WR & 1 with poor and 1 with middle WR \\
Aspirations of Youth & 1 with poor & 1 poor \\
Capacity to Innovate & 1 with poor and 1 with middle WR & 1 with poor and 1 with middle WR \\
Total & $6(4$ with poor and 2 with middle WR $)$ & $6(4$ with poor and 2 with middle WR $)$ \\
\hline
\end{tabular}

The notes taken during the FGDs were translated and the recordings from the SSIs were transcribed and translated from Bangla to English immediately after data collection by professional translators and the data collection team. Both were imported to qualitative data analysis software NVivo 10 and coded using the software based on predefined codes by the WorldFish Bangladesh Gender Team and the GENNOVATE researchers.

Limitations for qualitative data analysis include the absence of verbatim transcripts for the FGDs, meaning that individual contributions and different points of view have been obscured. The transcripts for the SSIs offer more scope for narrative analysis. Moreover, the selection of 'innovators' by the key informants implies a need for caution in interpretation. In both FGDs and SSIs participants were asked - after discussion - to come to a definitive consensus about various issues. These 'agreed' variables have informed the analysis, but we acknowledge that they were produced in group settings where concerns about reputation and status may have influenced participant behavior in ways that don't reflect their private views. These formal variables are therefore explored, as far as possible, alongside other narrative contributions and with a certain amount of caution.

\section{Results}

We begin, firstly, by presenting gender norms and gender practices in the context of changing livelihoods and ongoing/emerging challenges for innovation and agricultural aquatic systems in the 6 villages. Secondly, we explore the ways in which innovations are gender differentiated. Thirdly, we look closely at the ways in which different men and women are (or are not) able to make or find space to innovate and what this means for restrictive norms.

\subsection{Changing Gender Norms and Varied Gender Practices}

Both Hindu and Muslim communities across the villages expressed strong moral concerns about women's mobility and see male control over women's mobility as strongly tied to female honor. As a 'poor' woman in village 5 says: "A good wife is someone whose husband does not allow her to go out". Behind this consensus, though, there are variations in norms in the study communities. The mobility of women from Hindu households is generally understood to be more flexible than that of women from Muslim households. Although in practice, inheritance practices are gender-inequitable in both communities, there is in theory a provision for Muslim women to inherit a small share of property. Whilst mobility is often more guarded, and veiling/purdah more practiced, in higher-caste Hindu households and higher-class Muslim and Hindu households, this is not necessarily the case as some well-educated families adopt a more liberal approach.

Gender norms that were repeatedly expressed by all participants in the villages concerned men's 'breadwinning roles' in terms of their primary responsibility for the agricultural fields, for earning money and providing for their family as well as around women's 'homemaking' roles in terms of their responsibility for housework, for childcare, and for pleasing her husband. Despite this, there was a general recognition that women did a great deal of productive work 'at home' (i.e., within the homestead) including gardening on plots beside or near the home and 'helping' husbands on their fields. Whilst women's 'help' in generating income was valued by men, the strong preference they articulated for this to be done without leaving the homestead - whether it be by cultivating a garden plot, by selling goods from their houses or in some cases by tutoring children in their homes - nor at the expense of her reproductive duties.

There was also consensus across participants that gender norms were changing and that some gender differences have narrowed in all the villages over the last 10 years. This was seen by key informants to be due to more work opportunities for women, better access to credit, and more female council members, improved market access to most villages and better education for girls. Almost all girls were reported by respondents to be attending primary school across the villages, and about three-quarters of girls to be attending secondary schools in most 
villages. Although respondents also indicated that a significant minority of girls still are withheld from secondary school, this nevertheless reflects a massive increase in the levels of female schooling in the past decade. Interestingly, almost all girls were reported to attend secondary school in two villages - the predominantly Muslim village 1 and the predominantly Hindu village 4.

Many women across the villages now engage in vegetable cultivation and poultry-rearing at their homes. Participants reported that generally improved communications help equalize prices between smaller and larger markets and increase the opportunities to sell to traders at the farm gate. Both men and some women from some of these villages are becoming teachers, workers in factories and employed in NGOs. However, as table 4 shows, the outcomes of these changes for women's participation and visibility in economic activities vary across the villages in complex ways.

Women's visibility as sellers in the local markets is generally low and they are almost entirely absent in the markets in villages 3 and 5. The workforce participation of women in agricultural and non-agricultural work also remains mostly very low, with the notable exception of village 4 where female labor migration is also significantly more established. Whilst village 4 is less dynamic in economic terms, it has high level of female education and key informants reported women visible in business, professional employment and women's development. Whilst agricultural wages for women are only half that for men in villages 2, 5 and 6 , the agricultural wage gaps are closer in the other three villages. Agricultural laboring is generally seen in Bangladesh as low-class work and the meaning of higher or lower levels of women's agricultural laboring are not simple to interpret.

Table 4. Key gender markers reported in community profile group interviews

\begin{tabular}{|c|c|c|c|c|c|c|c|}
\hline Village & $\begin{array}{l}\% \text { sellers in } \\
\text { local market } \\
\text { who are } \\
\text { women* }\end{array}$ & $\begin{array}{l}\text { Women's } \\
\text { daily wage } \\
\text { as \% of } \\
\text { men's }\end{array}$ & $\begin{array}{l}\% \text { women doing } \\
\text { agricultural laboring } \\
(10 \text { years ago })\end{array}$ & $\begin{array}{l}\% \text { Women doing } \\
\text { other jobs in the } \\
\text { village (now and } \\
10 \text { years ago) }\end{array}$ & $\begin{array}{l}\% \text { women } \\
\text { migrate } \\
\text { work } \\
\text { compared to } \\
\text { years ago)* }\end{array}$ & $\begin{array}{l}\text { who } \\
\text { for } \\
\text { (as } \\
\text { to } 10\end{array}$ & $\begin{array}{l}\% \text { of households } \\
\text { with men who } \\
\text { migrate } \\
\text { permanently* }\end{array}$ \\
\hline 1 & Approx. 25\% & $80 \%$ & $20 \%(80 \%)$ & $5 \%(2 \%)$ & $\begin{array}{l}\text { Almost } \\
\text { (decr.) }\end{array}$ & none & Approx. 25\% \\
\hline 2 & Approx.25\% & $50 \%$ & $10 \%(2 \%)$ & $2 \%(0)$ & $\begin{array}{l}\text { Approx. } \\
\text { (increase) }\end{array}$ & $25 \%$ & Approx.. 10\% \\
\hline 3 & Almost none & $66 \%$ & $15 \%(5 \%)$ & $3 \%(0)$ & _ (same) & & Approx. 50\% \\
\hline 4 & Approx. 25\% & $70 \%$ & $30 \%(0)$ & $40 \%(10 \%)$ & $\begin{array}{l}\text { Approx. } \\
\text { (Increase) }\end{array}$ & $50 \%$ & Approx. 75\% \\
\hline 5 & Almost none & $50 \%$ & $10 \%(20 \%)$ & $20 \%(8 \%)$ & $\begin{array}{l}\text { Almost } \\
\text { (decrease) }\end{array}$ & none & Approx. 25\% \\
\hline 6 & Approx. 25\% & $50 \%$ & $40 \%(0)$ & $5 \%(1 \%)$ & $\begin{array}{l}\text { Approx. } \\
\text { (increase) }\end{array}$ & $25 \%$ & Approx. 50\% \\
\hline
\end{tabular}

*For these variables, participants had to select between: almost none, around 25\%; around 50\%; and almost $100 \%$.

The villages also varied in how far gender norms were reported to affect gender workforce participation at different points in women's life course. Gender norms restricting mobility bear particularly heavily on young unmarried women and young married women, who are in addition further constrained by reproductive responsibilities. Key informants said that a decade ago it was 'rare' for single young women or young married women to work for pay in any of the villages (table 5) but that workforce participation was likely for older married women in three of the villages (1,2, and 4) and for widows in two of these (villages 2 and 4). In contrast, key informants in all the villages reported that currently they perceived it to be 'common' for older married women to work. This represents a significant change in the acceptability of women's work outside the home. Such a decisive change was not evident for younger women, although it was said to have become common for 
younger married women to work in three of the villages (3, 5 and 6) and for young single women to work in villages 3 and 6 .

Table 5. The reported likelihood of women working for pay across the life course

\begin{tabular}{lllll}
\hline Village & \multicolumn{2}{l}{ Likelihood of women working for pay today: rare or common. } & & Widowed \\
\hline & Young single women & Young married women & Older married women & Rare \\
2 & Rare & Rare & Common & Rare \\
3 & Rare & Rare & Common & Rare \\
4 & Rare & Common & Common & Common \\
5 & Rare & Rare & Common & Common \\
6 & Common & Common & Common & Common \\
\hline
\end{tabular}

How then did women and men across the villages perceive their individual power and freedom to decide on important affairs in their lives? We asked each FGD to use a five-step scale to arrive at a score for their power today and a decade ago (Note 2): these are consensus scores and should be treated with caution. On average, in 2014, women's FGDs rated their level of power and freedom as moderate (3.1) as opposed to men who rated their level of power and freedom as high (4.4) confirming men's stronger agency to decide on important affairs in their lives. In terms of changes over time, whilst adult men's FGDs perceived that their power has been stable over the past decade, women's FGDs reveal a very marked rise in their self-perceived power over the last 10 years (from an average of 1.8 a decade ago). Women recognized that there is a significant rise of women's agency: both women's and men's FGDs attributed this mainly to improved access to education and training for women. Interestingly, there was relatively little difference in how young men and young women rated their power in 2014 (table 6). Although boys still scored higher than girls (averaging 3.4 as opposed to 3.1), both groups tended to see their power and freedom to make decisions as moderate. This may reflect improvements for girls and young women in this cohort, as well as less acknowledged restrictions on freedom for boys and young men.

Table 6. Ladder of power and freedom of women and men across villages as perceived by older and youth women and men focus groups

\begin{tabular}{lllll}
\hline Village & $\begin{array}{l}\text { Men FG } \\
\text { Adult }\end{array}$ & Youth & Adult & Youth \\
\hline 1 & 4 & 3 & 3 & 3.5 \\
2 & 5 & 4 & 2 & 3 \\
3 & 5 & 3.5 & 3 & 3 \\
4 & 5 & 3 & 4 & 3 \\
5 & 3.5 & 4 & 3.5 & 3 \\
6 & 4 & 3 & 3 & 3 \\
\hline
\end{tabular}

Step 1 or 2 is lacking of low power agency; step 3 moderate or start to grow power agency; and step 4 and 5 strong or rising power

\subsection{Gendered Innovations: Opportunities, Motivations and Norms}

Innovations in vegetable cultivation, livestock and poultry farming and aquaculture have played an important role in adapting to increasing salinity, in recovering from shocks and setbacks and in accessing new economic opportunities in these villages (table 7). Although South West Bangladesh is generally considered as a region in crisis as presented in the Context section, these villages report that their wellbeing and economic situations have improved over the last decade. 
Table 7. Innovations

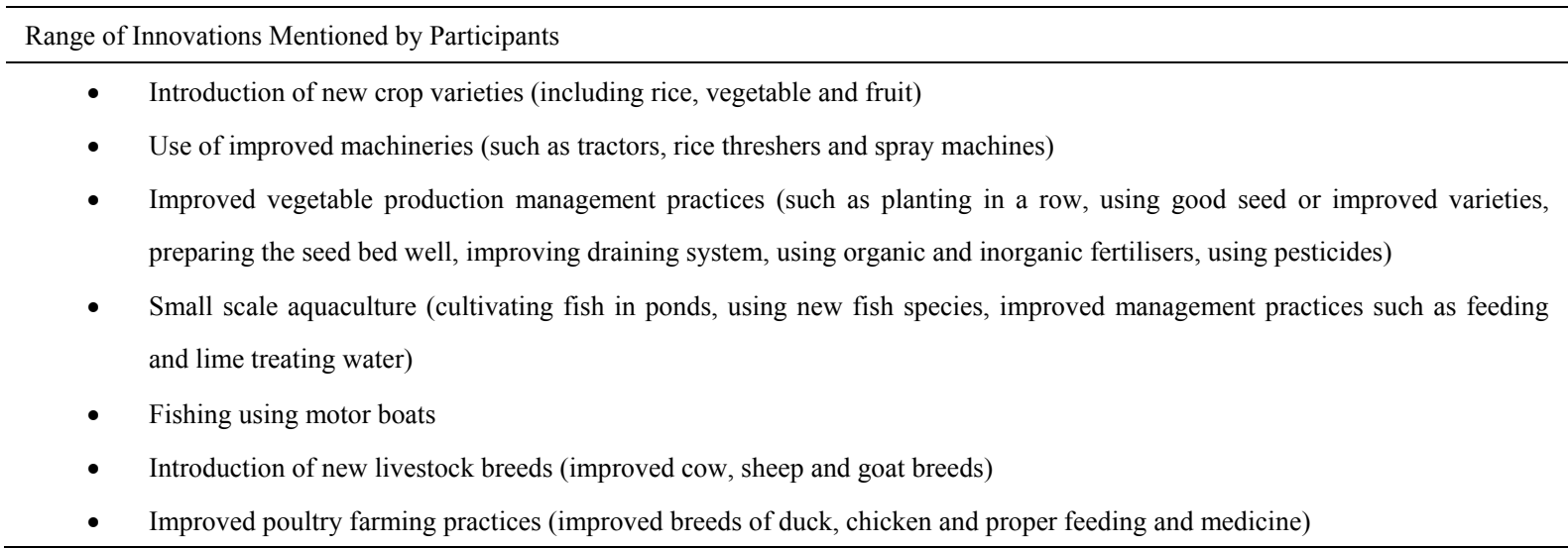

Innovations around vegetable production, fishing and sesame production are mentioned by both men's FGD and women's FGDs. However, poultry production and livestock keeping were only amongst 'the two most important innovations' for women's FGDs, whilst rice production was only amongst 'the two most important innovations' for men's FGDs. Whilst both men and women stress that the profitability and/or earnings from an innovation is key to their motivation, common gender differences in the priority accorded to productivity and subsistence also operate in these study villages (see figure 3). Men remarked on how successful agricultural innovation increased their reputation, their social recognition, and their ability to provide for their family and invest in other productive assets or businesses. Men's choices in innovation reflected their access to and/or control over land and quality water, the opportunity of bringing barren lands into production, their need to diversify cultivation, and existing gendered roles in agriculture. Women's choices of vegetable gardening, poultry and livestock were motivated by their 'fit' with the social disapproval of women moving beyond the homestead and their need to prioritize household work and childcare (according to two-thirds of women's FGDs). All women's FGDs noted that these innovations offer 'convenience' and over half agreed that the possibility of increased consumption of vegetables, meat and fish were major motivators.

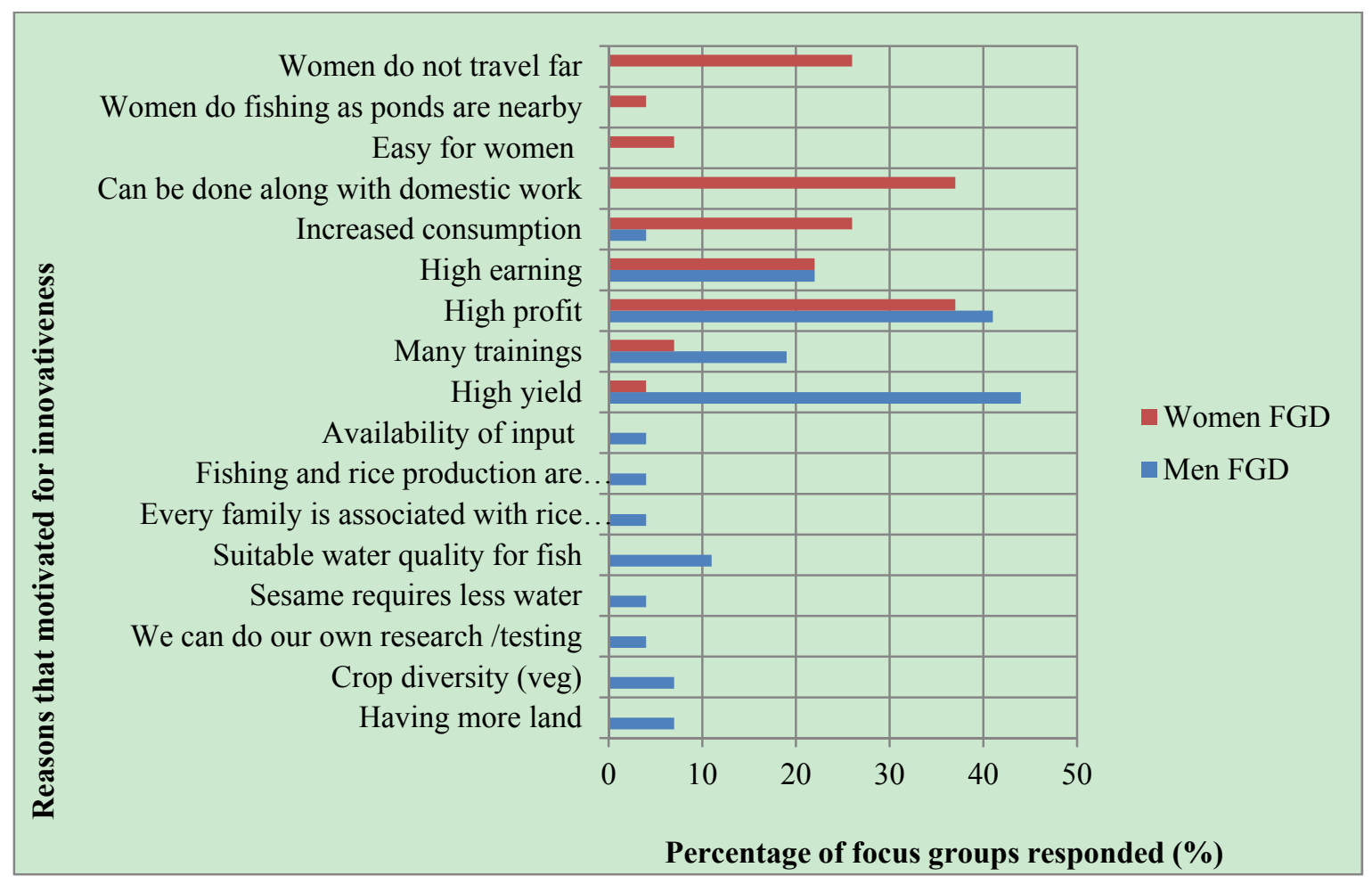

Figure 3. Main reasons for selecting innovations as agreed by Men's and Women's FGDs

Source: Separate women's and men's FGD from poor, middle wealth class, and youth groups ( $\mathrm{n}=36$ ) 
Investigation at village level reveals the context-specificity of the preferred innovations taken up by men and, to a lesser extent, women of different wealth ranks and ages (see table 8 and 9). Each FGD was asked to agree on the two most important innovation for them as a group, so this data does not capture individual variations. Most striking is the uniformity of women's interest in vegetable gardening and the relative diversity of men's interests in innovation, reflecting the impact of gender norms in shaping the options horizons of men and women. Whilst vegetable production was also identified as an important innovation by some men's FGDs in some villages, there are important differences in how men and women engage in vegetable production. Women vegetable growers use small plots of land in their backyards or very close to their houses, whilst all men who grew vegetables using innovative methods did so in bigger plots of land on their main fields. This reflects the realities of male control over farmland and the normative expectation that men allow their wives to engage in productive activities for the benefit of the family on the land around the house. A third of women's FGDs said that they did not need to negotiation much with their husbands to use this land. Poultry-keeping is relatively more important for younger women because they have relatively less entitlement to use homestead land than adult women.

Table 8. Men's top two most important innovations adopted over the last five years

\begin{tabular}{|c|c|c|c|c|c|c|c|c|c|c|c|c|c|c|c|c|c|c|}
\hline \multirow[t]{2}{*}{ New practices } & \multicolumn{3}{|c|}{ Village 1} & \multicolumn{3}{|c|}{ Village 2} & \multicolumn{3}{|c|}{ Village 3} & \multicolumn{3}{|c|}{ Village 4} & \multicolumn{3}{|c|}{ Village 5} & \multicolumn{3}{|c|}{ Village 6} \\
\hline & $\mathrm{M}$ & $\mathrm{P}$ & $\mathrm{Y}$ & M & $\mathrm{P}$ & $\mathrm{Y}$ & M & $\mathrm{P}$ & $\mathrm{Y}$ & M & $\mathrm{P}$ & $\mathrm{Y}$ & M & $\mathrm{P}$ & $\mathrm{Y}$ & M & $\mathrm{P}$ & $\mathrm{Y}$ \\
\hline Rice & $\sqrt{ }$ & $\sqrt{ }$ & $\sqrt{ }$ & - & $\sqrt{ }$ & $\sqrt{ }$ & $\sqrt{ }$ & $\sqrt{ }$ & $\sqrt{ }$ & $\sqrt{ }$ & - & $\sqrt{ }$ & $\sqrt{ }$ & $\sqrt{ }$ & $\sqrt{ }$ & - & $\sqrt{ }$ & $v$ \\
\hline Fish & $\sqrt{ }$ & $\sqrt{ }$ & $\sqrt{ }$ & $\sqrt{ }$ & $\sqrt{ }$ & $\sqrt{ }$ & $\sqrt{ }$ & - & - & - & - & $\sqrt{ }$ & - & - & $\sqrt{ }$ & - & - & - \\
\hline Vegetable & - & - & - & $\sqrt{ }$ & - & $\sqrt{ }$ & - & $\sqrt{ }$ & $\sqrt{ }$ & $\sqrt{ }$ & - & - & - & - & - & $\sqrt{ }$ & $\sqrt{ }$ & $\sqrt{ }$ \\
\hline Sesame & - & - & - & - & - & - & - & - & - & - & - & - & $\sqrt{ }$ & $\sqrt{ }$ & - & - & - & - \\
\hline
\end{tabular}

M: middle WR adult men, P: poor WR adult men, and Y: poor WR male youth ( $\mathrm{n}=18$ FGDs)

There are variations in the most important innovations for men and women from different villages, wealth ranks and age groups. In part these reflect differences in context-specific opportunities and constraints. For instance, fish farming was particularly important in villages 1 and 2 across all men's FGDs because salinity is a very serious problem in both villages. Similarly, aquaculture was only mentioned as important for middle wealth rank women in village 4 because this is the only village where fish ponds are sited close to homesteads and because only middle wealth rank households here have sufficient land for fish ponds.

Table 9. Women's top two most important innovations adopted over the last five years*

\begin{tabular}{|c|c|c|c|c|c|c|c|c|c|c|c|c|c|c|c|c|c|c|}
\hline \multirow[t]{2}{*}{ New practices } & \multicolumn{3}{|c|}{ Village 1} & \multicolumn{3}{|c|}{ Village 2} & \multicolumn{3}{|c|}{ Village 3} & \multicolumn{3}{|c|}{ Village 4} & \multicolumn{3}{|c|}{ Village 5} & \multicolumn{3}{|c|}{ Village 6} \\
\hline & M & $\mathrm{P}$ & $\mathrm{Y}$ & M & $\mathrm{P}$ & Y & M & $\mathrm{P}$ & $\mathrm{Y}$ & M & $\mathrm{P}$ & $\mathrm{Y}$ & M & $\mathrm{P}$ & $\mathrm{Y}$ & M & $\mathrm{P}$ & $\mathrm{Y}$ \\
\hline Vegetable & $\sqrt{ }$ & $\sqrt{ }$ & $\sqrt{ }$ & $\sqrt{ }$ & $\sqrt{ }$ & $\sqrt{ }$ & $\sqrt{ }$ & $\sqrt{ }$ & $\sqrt{ }$ & $\sqrt{ }$ & $\sqrt{ }$ & $\sqrt{ }$ & $\sqrt{ }$ & - & $\sqrt{ }$ & $\sqrt{ }$ & $\sqrt{ }$ & $\sqrt{ }$ \\
\hline Poultry & $\sqrt{ }$ & $\sqrt{ }$ & $\sqrt{ }$ & - & - & - & $\sqrt{ }$ & - & $\sqrt{ }$ & - & - & $\sqrt{ }$ & - & - & $\sqrt{ }$ & $\sqrt{ }$ & - & $\sqrt{ }$ \\
\hline Keeping livestock & $\sqrt{ }$ & - & - & - & - & - & $\sqrt{ }$ & $\sqrt{ }$ & - & - & $\sqrt{ }$ & - & - & - & - & - & - & - \\
\hline $\begin{array}{l}\text { Helping their husbands in paddy and } \\
\text { vegetable }\end{array}$ & - & - & - & - & - & - & - & - & - & - & - & - & - & $\sqrt{ }$ & - & - & $\sqrt{ }$ & - \\
\hline Fishing & - & - & - & - & - & - & - & - & - & $\sqrt{ }$ & - & - & - & - & - & - & - & - \\
\hline Sesame & - & - & - & - & - & - & - & - & - & - & - & - & $\sqrt{ }$ & - & - & - & - & - \\
\hline
\end{tabular}

M: middle WR adult women, P: poor WR adult women, and Y: poor WR female youth (n=18 FGDs)

(*Some women's FGDs named different vegetables as their top two most important innovations)

The SSIs reveal the importance to respondents of the approach in intervention-based innovation. Specifically, participants underscored that they valued the approach of the program that -- in contrast to their experiences with some NGOs - did not require participants have to take on any loans and are given what they needed to test out the new techniques. Respondents also attached significant importance to the close relationship they had with named program officers who supported them beyond the experimental phase when problems (such as pests or 
fungus) arose. These intervention characteristics were particularly important for women given their lack of capital to invest and the importance of a trusting relationship with intervenors for gaining their family's approval to participate.

Finally, women indicated that they do not only gain from, and are not only involved with, innovations that they name: women noted that they also gained from and helped husbands and sons in innovations led by men. In table 7, the most important innovation for poor women in villages 5 and 6 is their husband's rice and vegetable cultivation and for middle wealth rank women in village 5 it is their husband's sesame production. The reverse is also true: as we will see below, men indicated that they gained from and helped women in women's innovations as well. These interactions are not straight-forward and reveal both inequalities as well as strategic maneuvering that complicates assessment of their gendered impact.

\subsection{Which Gender Norms Matter for Innovation for Whom, When and Why?}

Key informants were asked to identify 'innovators' their communities. The innovators identified are likely to represent those that the key informants perceived to be 'model' innovators. However, almost all 'life history' respondents also reported innovation in the form of taking up new activities and almost all participants reported adoption of improved vegetable cultivation. Without exception, adopters report that relatives and neighbors quickly took up the same techniques of vegetable cultivation when they saw their success.

However, there were differences in how far and how hard women had to negotiate to start new homestead gardens or to develop existing ones. Despite strong evidence of success with new techniques for vegetable cultivation, a small minority of women cannot get permission to get involved at all. Flat out resistance by husbands was found in only two SSIs (Note 3); in both cases the resistance is focused on participation with an NGO through a group, rather than the innovation itself. In one case, a 32-year-old Muslim woman from village 3 was prevented by her husband from any involvement with development organizations because "I have to go outside the family.. [and] ... "get acquainted with a male person". Similarly, in the other case, a 32-year-old Muslim man in village 6 said: "I didn't allow my wife to join with WorldFish. Women don't need to do this kind of work".

Although the woman from village 3 is denied permission to join development organisations, she is earning income. She began private tutoring with her father's encouragement before marriage, and her husband ensures that she can continue teaching from home despite her mother-in-law's objections. He supports her because "he has seen that it is beneficial to him rather than any loss" and will even look after the children when she is teaching. She used to give her earnings directly to her husband, but 2 years ago opened her own savings account for them. Although she is happy in her marriage, she rates herself as having very little power, "all my decisions depend on my husband", and whilst "respect for me in my family increased as I am earning money and supporting the family financially, I have to do all the household works alone".

The more general picture from the data suggests that norms that prevent women joining NGO activities are negotiable where it brings benefits to the household. Whilst some women had to persuade their husbands to allow them to join the WorldFish program or to support them in developing their vegetable cultivation, others joined as part of what starts as or else becomes a joint strategy, and yet others because their husband asked them to. A 35-year-old Hindu woman from village 1 says simply that "my husband decided about my involvement with WorldFish" and several male respondents with busy livelihoods noted that they encouraged their wife to join as they don't have time to get involved or grow vegetables themselves. Tellingly, the man from village 6 who blocked his wife's participation in development organisations, boasted that he had taken a loan from an NGO "in his daughter's name". In other cases, there was more active discussion: as a 58-year-old Muslim female innovator Village 2 reports "I discussed with my husband. He encouraged me and told me "you do the gardening, we may live comfortably"”.

In almost all cases women acknowledge the importance of the 'cooperation' of their husband, adult sons, and in-laws (when the family is still living jointly), in enabling them to join the program and develop their vegetable cultivation. In these cases, cooperation ranges from tolerance of women's involvement and the mobility that it involves, through to explicit encouragement and helping her with marketing and heavier tasks. In several cases, a close bond between husband and wife seems to be key to women's ability to negotiate around the disapproval from in-laws. More commonly though, the inverse was found: wives noted that their relationships with their husbands had become better because of their successful innovation, as we will discuss further below.

The SSIs data also reveals that female program officers played an important role in handling tensions between husbands and wives as well as social pressure from the wider community. For instance, in village 5 a 30 -year-old Hindu innovator says that her husband initially objected to her gardening and laughed at her efforts until a 
female program officer "convinced" him to support her. A 43-year-old Hindu woman, also from village 5, who is a 'farmer researcher' with WorldFish reports that her neighbours "used to call me with criticizing voice 'lady leader'...”. Similarly, a 27-year-old unmarried Muslim woman from this village says that when WorldFish first came to work with women that:

"other people were laughing. They used to say 'what are women doing along with that woman [naming the Woman Officer for WorldFish]? Why are they digging land? What will they do? Women will be researchers, we never heard [of that before]'.

Now, she notes that villagers have a good relationship with the female field officer and that almost all have taken up vegetable gardening techniques that she promotes.

Whilst on the surface, the identified gender norms might suggest that decision-making and innovation is unproblematic for men, the SSI interviews provide more complex insights about the way in which different men also negotiate for support for their innovative actions. For example, a 55-year-old Hindu man from village 2 says "I discussed [the innovations] with my family and my wife told me 'what will you do with this?' but when I started to do cultivation with this new technique [and she saw its good results], she gave me permission to do it". Young unmarried men live in their father's house and have no land of their own. Motivation for them is to do with independence: as a 26-year-old Muslim man from village 3 was that now "I don't need to depend on any other people in my life". Like the other young unmarried men interviewed, he emphasized that he needed his father and mother's permission to try out innovations on their land. Moreover, whilst most adult men rated their power and freedom to make decisions as high, their narratives suggested that this was often experienced as responsibility more than freedom. For instance, a 43-year-old Muslim man from village 2 notes that when his father died the "whole burden of my family came down to me". A 43-year-old man also from village 2 says "I am the only man in my family - I have to take care of my house and stay alert for trouble - if I didn't follow their [his wife's and his mother's] suggestion and work failed, nobody will protect me". Older men noted how their power diminished as their sons grew up but do not necessarily see this as a bad thing. A 45-year-old Muslim man from village 3 used to make all the decisions himself but says that "now my children are older" that he shares making decisions with them. He does little heavy work now and takes satisfaction in seeing his sons thriving as adults.

A related area of findings is that the common interests of husbands and wives subtly influences authority within the household. Many reported that financial management was shared and that wives were responsible for daily expenditures. In village 3, a 54-year-old Muslim man noted that "my wife manages all the money we need. She decides all the expenses of the family" and in village 4, a 35-year-old woman, tells us that "I myself do the financial management... I make lists and my husband brings from market". Some women are also responsible for very significant investments in their families. Almost all women own jewelry after marriage, around $5 \%$ of land across the villages is reported to be owned by women (as a result of Muslim inheritance and some purchases) and several NGOs target women for loans. A 35-year-old Muslim woman from village 6 says that: "I bought land jointly with my husband. It is in his name because he loves me and does not quarrel with me. I bought this land, so we could produce more crops, without my money the land would not have been bought". She financed her share of the purchase by selling her inherited land to her brothers. Similarly, a 30-year-old Muslim woman from village 3 says that she "bought a power tiller jointly with my husband". She emphasises that her money - from her father and from her private tuition - was vital to making the purchase. A 38-year-old woman from village 4 narrates the key turning point in her married life cam when "I brought a piece of land but in the name of my husband". She continues: "My husband supported me a lot. I took loan from ASHA [an NGO], gave him to do business and he repaid that loan".

Repeatedly, women in life history as well as innovator interviews referred to how their successful innovation increased their honour (kodor (Note 4)) and respect, led to them being more valued, and their opinions more listened to and having more say in decisions, and to improved relations with their husbands. A 44-year-old Hindu woman from village 4 puts it succinctly: "My respect is enhanced because I am not [sitting and] eating idle". Another 38-year-old married Muslim woman says: "As my family no longer need to buy vegetable with cash, we can save. My honour is increasing as I am earning."

Some female innovators see their agricultural innovation as 'life changing'. For instance, a 46-year-old Muslim woman innovator in village 2 experienced a very significant rise in power and freedom to decide things in her life over the last decade and attributes this to her new earnings from vegetable production and rearing ducks and goats: "I think behind this is my economic progress... Nobody did value me, nowadays they know that my suggestions bring good result for all". Not all women report such large increases in decision-making power, but 
all identify significant, if smaller, gains. Although women valued the innovations for consumption too, they tied increases in their respect, honour and decision-making in the eyes of others tightly to earnings and valued highly the financial contributions they made to improving their children's lives. For instance, a 27-year-old Hindu woman from village 4 says "Some cash is coming to my own hands [so] I am able to meet my son's needs. This is most important to me". Women also noted that their skills and knowledge were respected by neighbours and have gained confidence in groups and in addressing officers. As a 27-year-old Hindu woman innovator from village 4 said: "I was not able to talk to people properly. This year ... I addressed around 200 people" at a World Fish meeting. It is notable that men, as well as women, report learning from their wives or mothers as well as from women NGO staff.

Interestingly, women linked support from their husband to love and almost all remarked on how their successful innovation improved their relationship with their husbands. For instance a 35 -year-old from village 4 says: "My husband cooperates with me a lot... I am involved with several NGOs. I need to go outside the home for attending the meetings. If my husband restricts me, I may not come so far... He loves me, so he cooperates with me". A 27-year-old Hindu woman from village 4 concurs: "[My husband] love me more nowadays. I am earning nowadays". FGD discussions of hypothetical scenarios of negotiations between husbands and wives also referred to love. In village 4, whilst women emphasized that a wife should use 'reasoning' to persuade husbands to support her point of view in a negotiation, men emphasized that a wife should "make her husband understand through love".

Indeed, many men approvingly reported more equitable gender norms had developed around women's agricultural innovation and their participation in NGOs. For a 55-year-old Hindu male innovator from village 2 says that: "men and women are now working together for their financial improvement. In the past, women used to sit in the house and didn't do any outside work at all. But now women are doing cultivation in their barren lands besides their housework". Such statements neglect women's earlier contributions to productive livelihoods and downplay their frequent cultivation of the household plot using older techniques, but nevertheless articulate male approval of women's innovation and their contribution to improving livelihoods. A 55-year-old Muslim male innovator from village 2 said: "women are doing some vegetable cultivation by themselves and taking some load off from men by earning some money themselves". Almost all women noted that they do this work in addition to their existing household chores, and a few noted the "physical burden" that this incurred. This was often explicitly recognized by men who frequently identified their wives as the most important people in their lives and acknowledged their wives' additional work effort as 'help', using the phrasing "she works not only as a homemaker" of "she helps me more than other wives".

\section{Discussion and Conclusion}

The findings show that there is a strong consensus around broad gender norms but that there are subtle variations in gender norms and their application in different places to different people, and that some gender norms are flexing and yielding in the face of wider changes in Bangladesh's society and economy (as per findings presented in section 3.1). The findings suggest that the impact of norms on gendered behaviours is complex to interpret, but is closely linked to economic conditions, social identity and life course positions. This confirms Jahan and Farnworth's view (2014, p.11) that there are "no easy associations between gender norms and specific gender characteristics".

Gender norms and access to and control over assets powerfully mediate the ways in which innovations are gendered (as evidenced in section 3.2). This is manifest, for example, by the predominance of vegetable cultivation on the homestead in women's innovations, whether predominantly Muslim or Hindu, and regardless of wealth ranks. This innovation accommodates gender norms, is facilitated by women-targeted initiatives, and made possible by women's normative access to land in the homestead and the fact that they do not need to take on loans or invest in new inputs to get started. The key gender negotiation involved here has been around women's involvement with NGOs, particularly the regular movement it involves attending meetings within the village, the occasional movement beyond the village to attend training, and the interactions during these events with unrelated male staff. This confirms Mahmud, Asadullah, \& Savoia (2013) observation that NGO-led development that targets women for service delivery model has potentially shaped mobility norms making it more acceptable for women to venture outside of the home. We would add that approval for mobility within the village is highly qualified: whilst almost all (married) women can gain approval to attend program meetings in the village, women remain largely invisible as sellers in local markets. Quisumbing et al's (2015, p. 713) point that the increasing acceptability of mobility within the village does not necessarily lead to any improvement in women's mobility beyond the village. Our findings add to this understanding about the resilience of norms that constrain women's mobility by showing that legitimating women's mobility for one purpose within the village 
does not necessarily lead to improvements in women's general mobility within the village.

Women's new income has been highly valued by them and recognized by their families. Yet this shift is complex and not without qualifications. The findings (sections 3.2 and 3.3) show that support for both women's innovation is enabled by common or overlapping interests of husbands in wives' innovations and that male incomes have also substantially increased in these villages because of innovations promoted by NGOs. Would women's innovation have been welcomed in the same way if they did not direct their new income towards benefitting the family, if NGOs did not also work with men or if male incomes were declining? Indeed, the relationship between women's innovation and women's empowerment is often ambiguous: some women participated on their husbands orders and whilst there has been some stretching of gender norms to support women's innovation, the changes are limited and contingent on their cultivation being bounded by the homestead, on benefits for the family, and on women completing their household chores first. As such, in this accommodative sphere, women's innovations here are small in scale, require little investment, and thus can only have a very limited impact on the gendered economics of the household.

Nevertheless, in this context, women who innovate, and men who support women's innovation, use gender norms in complex and ambiguous ways. This may include reinterpreting some gender norms in ways that resonate with the gender empowerment goals of development interventions whilst, at the same time, preserving gendered family values and wider social norms about gender roles. This is not without contradiction and ideas about 'honour' and 'love' may be being deployed strategically to defuse and reward men's support of women's agency, as well as to disguise women's expression of their strategic interests. Similarly, NGO interventions target women in ways that acknowledge and show accommodation to existing gender norms on mobility even at the same time as they promote new ideas about women's roles and activities. The outcomes of qualified legitimizing of (most) women's participation with development NGOs and of their income earning from the homestead are significant changes but cannot be described as transformative.

In conclusion, gender norms matter and that they play a vital role in maintaining wider structural constraints on women's innovation. Nevertheless, some renegotiation of some gender norms appears possible where there are strong common interests between men and women in doing so. These negotiations may be significant locally whilst also being closely bounded. In this case, mobility within the village has become increasingly accepted for women to attend group meetings with development NGOs where there are clear benefits to the whole family. The success of the innovation and the benefit it brings to her family's economic situation is critical for approval of women's innovation. In agreement with development thinking, this increase in her earnings and economic contribution to the family has led to an increasing value being placed on women's opinion and her power within the family. However, these changes fall substantially short of transforming gender relations in agriculture.

Importantly, our findings show the importance of a palatable vision of women's empowerment that enhances women's honour and strengthens family relationships for ongoing support of women's innovation. From a more critical perspective, we need to also attend to the ways in which accommodative interventions (Note 5) may be obscuring that support for women's empowerment in this context is explicitly dependent on her earnings improving the economic position of the family, on getting household work done, and on maintaining observance of wider mobility restrictions. In other words, the stretching of gender norms needs to be understood in relation to changes, or the lack of them, in material gender relations.

What does this mean more broadly for gender and agricultural innovation? Whilst reaffirming the value of gender-accommodative approaches for research and development, the findings suggest three important points. Firstly, that there is value in attending more closely to how specific gender norms influence the capacity of different men and women to innovate. Technical organisations seeking to promote innovation need to go beyond itemizing gender 'gaps' to engage more closely with the way underlying gender norms influence various women's, and men's, motivations, spheres of innovation, and their valuations of outcomes. Secondly, that local narratives from men and women about changing gender relations need to be examined critically rather than taken at face value. And thirdly, that a more transformative approach towards promoting agricultural innovation is likely to be required to achieve more significant changes in wider gender relations.

\section{Acknowledgements}

This work was undertaken as part of the CGIAR Research Program on Fish Agri-Food Systems (FISH). Funding support for this study was provided by the CGIAR Research Program on Aquatic Agricultural Systems (AAS) and CGIAR Research Program on Fish Agri-Food Systems.

The authors also acknowledge the efforts of many individuals and stakeholders who made this study possible. We are grateful for the technical support of GENNOVATE (Enabling Gender Equality in Agricultural and 
Environmental Innovation) for facilitating the data collection through developing the qualitative data collection tools and helping with the analysis of data by organizing a number of forums. We are also grateful for the support from the Bangladesh Center for Communication Programs (BCCP) during data collection.

Special thanks to the women and men of the communities in Satkhira, Khulna and Barguna who were willing to participate in the research process, devote their time and share their valuable knowledge. We also acknowledge the contribution of the late Paula Kantor, WorldFish for initiating this study. We also appreciate the contributions of Miranda Morgan. Finally we sincerely thank the WorldFish gender teams and AAS teams from Bangladesh who supported the field work and undertook the coding of the interviewees.

\section{References}

Agarwal, B. (1997). "Bargaining" and gender relations: In and beyond the household. Feminist Economics, 3(1), 1-51. https://doi.org/10.1080/135457097338799

Asadullah, M. N., \& Wahhaj, Z. (2016). Missing from the market: Purdah norm and women's paid work participation in Bangladesh IZA DP No. 10463, IZA (Institute of Labour Economics), Bonn.

Badstue, L., Kantor, P., Prain, G., Ashby, J., \& Petesch, P. (2014). Innovation and development through transformation of gender norms in agriculture and natural resource management. Concept note for GENNOVATE. Montpellier: CGIAR.

Bennett, E. (2005). Gender, fisheries and development. Marine Policy, 29(5), 451-459. https://doi.org/10.1016/j.marpol.2004.07.003

Carr, E. R., \& Thompson, M. C. (2014). Gender and climate change adaptation in agrarian settings: Current thinking, new directions, and research frontiers. Geography Compass, 8(3), 182-197. https://doi.org/10.1111/gec3.12121

Cornwall, A. (2016). Women's empowerment: What works? Journal of International Development, 28(3), 342-359. https://doi.org/10.1002/jid.3210

CRP AAS [CGIAR Research Program on Aquatic Agricultural Systems]. (2012). Resilient livelihoods and food security in coastal aquatic agricultural systems: Investing in transformational change. Project Report: $A A S-2012-28,1-18$. Penang: CGIAR Research Program on Aquatic Agricultural Systems.

Elmhirst, R., \& Resurreccion, B. P. (2008). Gender, environment and natural resource management: New dimensions, new debates. In B. P. Resurreccion \& R. Elmhirst (Eds.), Gender and natural resource management: Livelihoods, mobility and interventions (pp. 3-22). London: Earthscan.

Friis-Hansen, E., \& Duveskog, D. (2012). The empowerment route to well-being: An analysis of Farmer Field Schools in East Africa. World Development, 40(2), 414-427. https://doi.org/10.1016/j.worlddev.2011.05.005

Gill, K., Brooks, K., McDougall, J., Patel, P., \& Kes, A. (2010). Bridging the gender divide: How technology can advance women economically. Washington, DC: ICRW.

Goetz, A. M., \& Sen Gupta, R. (1996). Who takes the credit? Gender, power and control over loan use in rural credit programs in Bangladesh. World Development, 24(1), 45-63. https://doi.org/10.1016/0305-750X(95)00124-U

Holmes, R., Mannan, F., Dhali, H. H., \& Parveen. M. S. (2010). Gendered risks, poverty and vulnerability in Bangladesh. Case study of the Challenging the Frontiers of Poverty Reduction Programme (CFPR), Specially Targeted Ultra Poor II (STUP II). London, UK: Overseas Development Institute

Humphreys, S., Classen., Jimenez, J., Sierra, F., Gallardo, O., \& Gomez, M. (2012). Opening cracks for the transgression of social boundaries: An evaluation of the gender impacts of farmer research teams in Honduras, World Development, 40(10), 2078-95. https://doi.org/10.1016/j.worlddev.2012.05.008

IGWG [Interagency Gender Working Group Task Force Report]. (2004). The 'So What' Report: A look at whether integrating a gender focus into programmes makes a difference to outcomes. Washington, DC: Interagency Gender Working Group Task Force Report.

Jahan, R., \& Farnworth, C. R. (2014). Literature review on gender and wider social norms in South West Bangladesh. Retrieved from http://static1.squarespace.com/static/551bb3ade4b0404100c31678/t/558c0054e4b0443f864a11ba/14352384 84994/Farnworth+\%26+Jahan+Gender+\%26+Social+Norms+Bangladesh+2014.pdf 
Johnson, N., Lilja, N., Ashby, J. A., \& Garcia, J. A. (2004). The practice of participatory research and gender analysis in natural resource management. Natural Resources Forum, 28(3), 189-200. https://doi.org/10.1111/j.1477-8947.2004.00088.x

Kabeer, N. (1999). Resources, agency, achievements: Reflections on the measurement of women's empowerment. Development and Change, 30(3), 435-464. https://doi.org/10.1111/1467-7660.00125

Kawarazuka, N., Locke, C., McDougall, C., Kantor, P., \& Morgan, M. (2017). Bringing analysis of gender and socio-ecological resilience together in small-scale fisheries research: Challenges and opportunities. Ambio, 46(2), 201-213. https://doi.org/10.1007/s13280-016-0814-5

Khan, F. C. (2005). Gender violence and Development Discourse in Bangladesh. International Social Science Journal, 57(184), 219-230. https://doi.org/10.1111/j.1468-2451.2005.546.x

Lentisco, A., \& Lee, R. (2014). Beyond fish processors and caregivers: Women as primary, secondary and tertiary fish users. Gender in aquaculture and fisheries: Navigating change, 33.

Mahmud S. (2003). Actually how empowering is microcredit? Development and Change, 34(4), 577-605. https://doi.org/10.1111/1467-7660.00320

Mahmud, W., Asadullah, N., \& Savoia, A. (2013). Bangladesh's achievements in Social Development Indicators: Explaining the puzzle. IGC Policy Brief 31012. ICG International Growth Center, LSE, London.

Malhotra, A., Schulte, J., Patel, P., \& Petesch, P. (2009). Innovation for women's empowerment and gender equality. Washington, DC: International Center for Research on Women.

Meinzen-Dick, R., Quisumbing, A., Behrman, J., Biermayr-Jenzano, P., Wilde, V., Noordeloos, M., ... Beintema, N. (2011). Engendering agricultural research, development and extension. Washington, DC, USA: International Food Policy Research Institute.

Moore, M., \& Westley, F. (2011). Surmountable chasms: Networks and social innovation for resilient systems. Ecology and Society, 16(1). https://doi.org/10.5751/ES-03812-160105

Mosse, D. (1994). Authority, gender and knowledge: Theoretical reflections on the practice of participatory rural appraisal. Development and Change, 25(3), 497-526. https://doi.org/10.1111/j.1467-7660.1994.tb00524.x

Nokrek, P., \& Alam, A. (2011). Vulnerabilities and resilience among extreme poor people: The South West coastal region of Bangladesh. Working Paper No. 5. Dhaka, Bangladesh.

Ogunlela, Y. I., \& Mukhtar, A. A. (2009). Gender issues in agriculture and rural development in Nigeria: The role of women. Humanity \& Social Sciences Journal, 4(1), 19-30.

Okali, C. (2012). Gender analysis: Engaging with rural development and agricultural policy processes. Future Agricultures Working Paper 026. Brighton, UK: Future Agricultures Consortium.

Quisumbing, A.R., Rubin, D., Manfre, C., Waithanji, E., van den Bold, M., Olney, D., Johnson, N., \& Meinzen-Dick, R. (2015). Gender, assets, and market-oriented agriculture: learning from high-value crop and livestock projects in Africa and Asia. Agriculture and Human Values, 32(4), 705-725. https://doi.org/10.1007/s10460-015-9587-x

Ravindran, T. K. S., \& Kelkar-Khambete, A. (2008). Gender mainstreaming in health: looking back, looking forward. Global Public Health, 3(S1), 121-142. https://doi.org/10.1080/17441690801900761

Razavi, S., \& Miller, C. (1995). From WID to GAD: Conceptual shifts in the women and development discourse. UNRISD Occasional Paper 1, Geneva: UNRISD.

Solidarities International \& Uttaran. (2012). Chronic poverty in the South West belt of Bangladesh. Retrieved from https://www.solidarites.org/wp-content/uploads/2017/05/Chronic-poverty-Bangladesh-2012.pdf

Spielman, D. J., Ekboir, J \& Davis, K. (2009). The art and science of innovation systems inquiry: Applications to Sub-Saharan African agriculture. Technology in Society, 31(4), 399-405. https://doi.org/10.1016/j.techsoc.2009.10.004

Sproule, K., Kieran, C., Quisumbing, A. R., \& Doss, C. R. (2015). Gender, headship, and the life cycle: Landownership in four Asian countries. CGIAR Research Program on Policies, Institutions, and Markets Poverty, Health, and Nutrition Division. IFPRI Discussion Paper 01481. Washington DC. https://doi.org/10.2139/ssrn.2741111

Sraboni, E., Malapit, H. J., Quisumbing, A. R., \& Ahmed, A. U. (2014). Women's empowerment in agriculture: What role for food security in Bangladesh. World Development, 61, 11-52. 
https://doi.org/10.1016/j.worlddev.2014.03.025

Sumner, D., Christie, M.E., \& Boulakia, S. (2017). Conservation agriculture and gendered livelihoods in Northwestern Cambodia: decision-making, space and access. Agriculture and Human Values, 34(2), 347 362. https://doi.org/10.1007/s10460-016-9718-z

UNDP [United Nations Development Programme] (2016). Human Development Report 2016: Human Development for Everyone. UNDP, New York.

UNICEF [United Nations Children's Fund]. (2009). Child Poverty, Deprivation and Disparities in South Asia: Some Preliminary Findings and Policy Recommendations. Discussion Note. Kathmandu: UNICEF Regional Office for South Asia.

World Bank. (2008). Whispers to voices: Gender and social transformation in Bangladesh. Bangladesh Development Series Paper no. 22. Dhaka: World Bank. https://doi.org/10.1596/26334

World Bank. (2015). Bangladesh Country Snapshot. Washington DC: World Bank.

World Bank. (2016). The World Bank in Bangladesh. Washington DC: World Bank.

\section{Notes}

Note 1. Purdah is the practice of female seclusion from unrelated men.

Note 2. 5 represents strong power and freedom and 1 represents a lack of power or freedom.

Note 3. Out of 12 life history SSIs.

Note 4. Kodor is translated as honor but it also more closely means value, appreciation, worth, and importance.

Note 5. Gender-accommodative interventions "cater to the varying needs of women and men without challenging their gender roles" (Ravindran \& Kelkar-Khambete, 2008, p. 126).

\section{Copyrights}

Copyright for this article is retained by the author(s), with first publication rights granted to the journal.

This is an open-access article distributed under the terms and conditions of the Creative Commons Attribution license (http://creativecommons.org/licenses/by/4.0/). 